\title{
Cryptosporidium occurrence in ruminants from the North Pioneer mesoregion of Paraná, Brazil
}

\author{
Ocorrência de Cryptosporidium em ruminantes da mesorregião norte pioneiro do Estado do Paraná, Brasil
}

Luciane Holsback ${ }^{1 *}$; Heloísa Eid Lima ${ }^{1}$; Odilon Vidotto ${ }^{2}$; Marcelo Alves da Silva ${ }^{1}$; Thaís Helena Constantino Patelli ; Felippe Danyel Cardoso Martins²; Mércia de Seixas ${ }^{2}$

\begin{abstract}
${ }^{1}$ Setor de Veterinária e Produção Animal, Centro de Ciências Agrárias, Universidade Estadual do Norte do Paraná - UENP, Campus Luiz Meneghel, Bandeirantes, PR, Brasil

${ }^{2}$ Departamento de Medicina Veterinária Preventiva - DMVP, Centro de Ciências Agrárias, Universidade Estadual de Londrina UEL, Londrina, PR, Brasil
\end{abstract}

Received November 7, 2017

Accepted April 20, 2018

\begin{abstract}
The aim of this study was to investigate the occurrence of Cryptosporidium in cattle and sheep from the North Pioneer mesoregion of the state of Paraná. For this, 317 stool samples were collected from cattle and sheep on 16 properties in six municipalities in the North Pioneer mesoregion of Paraná. For detection of Cryptosporidium species, molecular analysis was performed using nested-PCR techniques targeting the 18S rRNA gene. Of the 37 beef cows and 115 calves analyzed, four (10.8\%) and 14 (12.2\%), respectively, were positive for Cryptosporidium. Of the 12 cows and 52 calves, one $(8.3 \%)$ and $14(26.9 \%)$, respectively, were positive for Cryptosporidium; and of the 42 ewes and 59 lambs, six (14.3\%) and 12 (20.3\%), respectively were positive for Cryptosporidium. Cattle (15.3\%) and sheep (17.8\%) were both susceptible to infection. All the properties of the municipalities of Assaí, Ibaiti and, Leópolis presented infected animals. The study showed that Cryptosporidium occurs in most municipalities assessed, that dairy calves had a higher risk (Odds Ratio=2,66, $p$-value $=0,018$ ) for infection than beef calves, and that sheep are just as susceptible to infection as are cattle, and that further Cryptosporidium studies are developed.
\end{abstract}

Keywords: Cryptosporidiosis, cattle, sheep, occurrence, Southern Brazil.

\section{Resumo}

O objetivo deste estudo foi investigar a ocorrência de Cryptosporidium em bovinos e ovinos da mesorregião norte pioneiro do Estado do Paraná. Para tanto, 317 amostras de fezes destes ruminantes foram colhidas de 16 propriedades de seis municípios do Norte Pioneiro do Paraná. Para detecção de Cryptosporidium spp foi realizada análise molecular pela Técnica de nested-PCR direcionada ao gene 18S rRNA. Das 37 vacas de corte e 115 bezerros de corte analisados, quatro $(10,8 \%)$ e $14(12,2 \%)$ foram respectivamente positivos para Cryptosporidium. Das 12 vacas e 52 bezerros de leite, um $(8,3 \%)$ e 14 (26,9\%) foram positivos para Cryptosporidium e das 42 ovelhas e 59 cordeiros avaliados, seis (14,3\%) e $12(20,3 \%)$ amostras estavam positivas para Cryptosporidium, respectivamente. Bovinos (15,3\%) e ovinos (17,8\%) foram igualmente suscetíveis à infecção. Todas as propriedades dos municípios de Assaí, Ibaiti e Leópolis apresentaram animais infectados. Este estudo demonstrou que Cryptosporidium ocorre na maioria dos municípios avaliados, sendo que os bezerros de leite apresentam maior risco (Razão de chances=2,66, $p$-value=0,018) à infecção que os bezerros de corte e que os ovinos são táo suscetíveis à infecção quanto os bovinos e por isso, estudos nesta espécie animal devem ser mais desenvolvidos.

Palavras-chave: Cryptosporidiose, bovinos, ovinos, ocorrência, Sul do Brasil.

Cryptosporidium is a genus of apicomplexan protozoan from the class Conoidasida, order Eucoccidiorida, and family Cryptosporidiidae; Cryptosporidium species have a life cycle that

*Corresponding author: Luciane Holsback. Setor de Veterinária e Produção Animal, Centro de Ciências Agrárias, Universidade Estadual do Norte do Paraná - UENP, Campus Luiz Meneghel, BR 369, Km 54, Vila Maria, CEP 86360-000, Bandeirantes, PR, Brasil. E-mail: lhsfertonani@uenp.edu.br is primarily completed within the gastrointestinal tract of a single host (LEVINE, 1985). However, new evidence suggests that the Cryptosporidium genus is included in the subclass Gregarina (CLODE et al, 2015).

In ruminants, the occurrence of Cryptosporidium has been linked to gastroenteritis in calves between 0 and 2 months of age and a high morbidity rate in dairy cattle (COKLIN et al., 2007; SANTÍN et al., 2008), calves prior to weaning and in newly weaned 
calves (AYINMODE et al., 2010; FAYER et al., 2008), and in older cattle (KVÁC \& VITOVEC, 2003; ROBINSON et al., 2006). In sheep, the highest infection rates are observed in the first few weeks of life (MARTINEZ \& BELDA, 2001), with increased infection rates up to 21 days (SANTÍN et al., 2007). Older lambs demonstrate delayed growth, and adults are generally refractory to infection and illness (XIAO et al., 1993), but can eliminate oocysts in the feces, thereby contaminating the environment (MAJEWSKA et al., 2000; ZUCATTO et al., 2015).

In Brazil, studies on cryptosporidiosis in ruminants have primarily been performed in the Southeast, mainly in the states of Rio de Janeiro (COSENDEY et al., 2008; FIUZA et al., 2011), Minas Gerais (GARCIA \& LIMA, 1993; GARCIA \& LIMA, 1994; LIMA et al., 2013), and Sáo Paulo (AQUINO et al., 2015; COELHO et al., 2016; FEITOSA et al., 2004; FÉRES et al., 2009; PAZ E SILVA et al., 2013, 2014; SEVÁ et al., 2010; SILVA-JUNIOR et al., 2011). In the state of Paraná, infection with Cryptosporidium was evaluated in captive birds (NAKAMURA et al., 2009), dogs with diarrhea (NAVARRO et al., 1997), horses (FUJII et al., 2014), wild birds and mammals (SNAK et al., 2015), cattle (TOLEDO et al., 2017) and sheep (SNAK et al., 2017). However, epidemiological studies have not been conducted on cryptosporidiosis in ruminants of the north pioneer mesoregion of Paraná. Knowledge about cryptosporidiosis among ruminants in this region of Paraná may have important implications in the field of veterinary public health, since this disease is a zoonosis. When results of this type of study are published, health surveillance agencies and other health professionals can alert the local population about hygiene measures necessary for the prophylaxis of the disease in animals and people living in the area. Thus, the present study aimed to evaluate Cryptosporidium infection and to determine its frequency of occurrence among adult and young cattle, dairy cows and adult and young sheep of the region.

Fecal samples of 317 ruminants who were apparently healthy, without symptoms of diarrhea, from 16 farms were chosen at random from six municipalities of North Pioneer, as follows: 75 samples from two farms in the municipality of Assaí, 63 samples from six farms in the municipality of Santo Antonio da Platina, 44 samples from two farms in the municipality of Ibaiti, 48 samples from three farms in the municipality of Ribeirão do Pinhal, 20 samples from one farm in the municipality of Ribeirão Claro, and 67 samples from two farms in the municipality of Leópolis. The period of sample collection was from August 2013 to May 2014. Of the 317 samples collected, 115 were from beef calves (aged $\leq 7$ months), 52 from dairy calves (aged $\leq 6$ months), 37 beef cows (aged $>3$ years), 12 dairy cows (aged $>3$ years), 59 from lambs (aged $\leq 4$ months), and 42 from ewes (aged $>1.5$ years). The collected samples were transported in a refrigerated condition to the Laboratory of Parasitology and Parasitic Diseases of the State University of North of Paraná; and an aliquot of each sample was separated and frozen until DNA extraction.

DNA extraction was performed using a commercial kitNucleoSpin ${ }^{\circledast}$ Tissue (Macherey-Nagel GmbH \& Co.) —and following the manufacturer's protocol, with three incremental freeze and thaw cycles before the lysis step in order to improve the rupture of oocysts (WELLS et al., 2015).

For the detection of Cryptosporidium species, a 826-840 bp fragment of the $18 \mathrm{~S}$ ribosomal RNA (rRNA) gene was amplified by nested polymerase chain reaction (PCR) with primers (XIAO et al., 1999).

Negative controls consisting of ultrapure water and positive controls consisting of $C$. parvum DNA were used in all batches. The products were subjected to $1.5 \%$ agarose gel electrophoresis, stained with SYBR Safe ${ }^{\circledast}$ (Invitrogen Co.), and photographically documented.

A descriptive variable analysis (positive/negative) was performed for Cryptosporidium infection in the populations of cattle and sheep, as well as for determining the odds ratio and their respective confidence intervals for the exposure variable (age, type, and category) and outcome (infection). The association between risks was assessed using Fisher's exact test, with significance set at $p$-value $<0.05$. Statistical analyses were performed using GraphPad Prism 6.01 (GraphPad Software, Inc.).

This project was approved (CEUA 3164-48) by the Comitê de Ética do Uso de Animais (CEUA), Universidade Estadual do Norte do Paraná.

Of the total 317 samples tested, 51 (16.1\%) were positive for Cryptosporidium. Of the 37 beef cows and 115 calves analyzed, four $(10.8 \%)$ and $14(12.2 \%)$, respectively, were positive for Cryptosporidium. Of the 12 cows and 52 calves analyzed, one (8.3\%) and 14 (26.9\%), respectively, were positive for Cryptosporidium; and of the 42 ewes and 59 lambs, six (14.3\%) and 12 (20.3\%), respectively, were positive for Cryptosporidium. However, statistically significant differences were found only between beef cattle and dairy cattle. These differences were related to higher infection rates among dairy calves (26.9\%) than among beef calves $(12.2 \%)$, $p$-value $=0.018$. Dairy calves were 2.7 times more likely to be infected with Cryptosporidium that were beef calves $(\mathrm{OR}=2.66$; CI 1.16-6.10\%)

A similar infection rate (28.1\%) was reported in dairy calves in Canada by using the Sheather's flotation method (COKLIN et al., 2007), but other authors have found higher occurrence rates of Cryptosporidium (43.6-82.1\%) using the modified Ziehl-Neelsen method (EDERLI et al., 2004), and Sheather's or Ziehl-Neelsen methods followed by PCR techniques (COUTO et al., 2014; TOLEDO et al., 2017). Of the 216 cattle evaluated, 33 (15.3\%) were positive for Cryptosporidium, as were 18 (17.8\%) of the 101 sheep. Although the rate of infection was higher in sheep, this difference was not significant $(p$-value $=0.57)$ (Table 1). Contrary to the results of this study, Villacorta et al. (1991) analyzed 141 cattle and 69 sheep and found infection rates of $6.38 \%$ and $1.45 \%$ respectively, using Ritchie's Technique modified by Allen \& Ridley (1970)

Although not significant $(p$-value $=1.15)$ there were more positive lambs (20.3\%) than beef calves (12.2\%). While comparative studies are scarce, an earlier study of 460 sheep in Araçatuba, São Paulo showed a $6.7 \%$ positive rate for oocysts using Sheather's flotation method, which is in agreement with our findings (FÉRES et al., 2009). In the same city, $12.4 \%$ of the calves were found to be positive using this same technique in a similar number of samples (FEITOSA et al., 2004). In the State of Paraná, recent research in the Western region showed high positivity in adult sheep (59\%), however the authors evaluated few lambs (7/144) (SNAK et al., 2017)

The infection rate among lambs was $43 \%$ higher than that seen in sheep. Although this difference was not significant, these 
Table 1. Distribution of positive and negative animals, relative frequency (\%), and statistical analyzes (OR - Odds Ratio, CI - Confidence Interval, p-value and $\chi^{2}$-Chi-square) of results from fecal tests for Cryptosporidium infection in adult and young cattle and sheep in the North Pioneer mesoregion of Paraná, Brazil.

\begin{tabular}{|c|c|c|c|c|c|c|}
\hline \multirow{2}{*}{$\begin{array}{c}\text { Variable } \\
\text { Animal category }\end{array}$} & \multicolumn{2}{|c|}{ Infection results } & \multirow{2}{*}{$\%$ Relative } & \multirow{2}{*}{ OR (CI) } & \multirow{2}{*}{ p-value } & \multirow{2}{*}{$\chi^{2}$} \\
\hline & Positive & Negative & & & & \\
\hline Beef cow & 4 & 33 & 10.8 & $\begin{array}{c}1.33 \\
(0.13-13.2)\end{array}$ & 0.805 & 0.06 \\
\hline Dairy cow & 1 & 11 & 8.3 & & & \\
\hline \multicolumn{7}{|l|}{ Species } \\
\hline Cattle & 33 & 183 & 15.3 & $\begin{array}{c}1.20 \\
(0.44-1.56)\end{array}$ & 0.57 & 0.33 \\
\hline Sheep & 18 & 83 & 17.8 & & & \\
\hline \multicolumn{7}{|l|}{ Age } \\
\hline Young & 40 & 186 & 17.7 & $\begin{array}{c}1.56 \\
(0.76-3.2)\end{array}$ & 0.22 & 1.51 \\
\hline Adult & 11 & 80 & 12.1 & & & \\
\hline \multicolumn{7}{|l|}{ Category/Specie/Age } \\
\hline Lamb & 12 & 47 & 20.3 & $\begin{array}{c}1.53 \\
(0.52-4.47)\end{array}$ & 0.43 & 0.61 \\
\hline Ewe & 6 & 36 & 14.3 & & & \\
\hline Calf & 28 & 139 & 16.8 & $\begin{array}{c}1.77 \\
(0.65-4.87)\end{array}$ & 0.26 & 1.26 \\
\hline Cow & 5 & 44 & 10.2 & & & \\
\hline Beef calf & 14 & 101 & 12.2 & $\begin{array}{c}2.66^{*} \\
(1.16-6.10)\end{array}$ & 0.018 & 5.58 \\
\hline Dairy calf & 14 & 38 & 26.9 & & & \\
\hline Beef cow & 4 & 33 & 10.8 & $\begin{array}{c}1.33 \\
(0.13-13.24)\end{array}$ & 0.8 & 0.06 \\
\hline Dairy cow & 1 & 11 & 8.3 & & & \\
\hline Beef calf & 14 & 101 & 12.2 & $\begin{array}{c}1.84 \\
(0.79-4.29)\end{array}$ & 1.15 & 2.05 \\
\hline Lamb & 12 & 47 & 20.3 & & & \\
\hline Dairy calf & 14 & 38 & 26.9 & $\begin{array}{c}1.44 \\
(0.59-3.48)\end{array}$ & 0.65 & 0.21 \\
\hline Lamb & 12 & 47 & 20.3 & & & \\
\hline Beef cow & 4 & 33 & 10.8 & $\begin{array}{c}1.38 \\
(0.35-5.31)\end{array}$ & 0.64 & 0.22 \\
\hline Ewe & 6 & 36 & 14.3 & & & \\
\hline Dairy cow & 1 & 11 & 8.3 & $\begin{array}{c}1.83 \\
(0.19-16.92)\end{array}$ & 0.59 & 0.29 \\
\hline Ewe & 6 & 36 & 14.3 & & & \\
\hline
\end{tabular}

*Significate difference $(\mathrm{p}<0.05)$

results were similar to those published by Causapé et al. (2002) and Paz \& Silva et al. (2014).

The variation in the infection rate, as determined by the presence of oocysts in the feces of animals infected with Cryptosporidium, is probably because of the form of laboratory diagnosis (for direct or molecular parasitological techniques) and also the clinical condition of the animals.

Techniques such as the modified Ziehl-Neelsen method, direct fluorescent antibody test, negative staining method or ELISA, with or without subsequent PCR, are widely used in the study of cryptosporidosis in ruminants. Among these techniques, PCR has the highest sensitivity (MORGAN et al.,
1998; REKHA et al., 2016; TAHVILDAR-BIDEROUNI \& SALEHI, 2014); moreover, the reported rates of occurrence of Cryptosporidium vary between studies (CAUSAPÉ et al., 2002; EDERLI, et al., 2004; FÉRES et al., 2009; PAZ \& SILVA et al., 2014; SNAK et al., 2017; TOLEDO et al., 2017). Higher infection rates are reported with the use of a stool oocyst-concentration technique, such as Sheather's flotation method (COKLIN et al., 2007; COUTO et al., 2014), probably due to its high sensitivity (REKHA et al., 2016). The discrepancy of sensitivity and specificity between the diagnostic techniques for Cryptosporidium occurrence indicates the need for multiple laboratory techniques for better reliability of the results. 
Table 2. Distribution of the total Cryptosporidium infection rates of beef calves, dairy calves, beef cows, dairy cows, lambs, and ewes for the municipalities of Assaí, Santo Antônio da Platina (Sto A Platina), Ibaiti, Ribeirão do Pinhal (Rib Pinhal), Ribeirão Claro (Rib Claro), and Leópolis in the state of Paraná, Brazil.

\begin{tabular}{cccccccc}
\hline Municipalities & Total (\%) & Beef calves (\%) & $\begin{array}{c}\text { Dairy calves } \\
(\%)\end{array}$ & Beef cows (\%) & Dairy cows (\%) & Lambs (\%) & Ewes (\%) \\
\hline Assai & 18.7 & 16.0 & 21.4 & 14.3 & 0 & 33.3 & - \\
Sto A Platina & 11.1 & 18.8 & 11.1 & 0 & - & 11.1 & -1 \\
Ibaiti & 36.4 & 33.3 & 46.7 & 33.3 & 16.7 & - & 0 \\
Rib Pinhal & 10.4 & 8.7 & - & 14.3 & - & 0 & 18.2 \\
Rib Claro & 0 & 0 & - & 0 & - & - & 0 \\
Leópolis & 13.4 & 8.0 & - & 0 & - & 29.2 & 0 \\
\hline
\end{tabular}

The present study did not used diarrheic samples. This may be one reason the infection rate found in this study was lower than that reported by several other authors, including Causapé et al. (2002), that analyzed 1-week-old lambs with diarrhea and found that 93.3\% of the animals were positive for Cryptosporidium infection, as determined by the Ziehl-Neelsen technique. Ayinmode et al. (2010) reported that $52.3 \%$ of PCR samples from calves with diarrhea in Nigeria were positive for Cryptosporidium infection and Garcia \& Lima (1994) found almost 60\% of the calves positive for Cryptosporidium infection as per the Ziehl-Neelsen technique had diarrhea. Other studies in ruminants-regardless of the presence of diarrhea - have shown infection rates lower (0-12.4\%) than those reported in the present study (COKLIN et al., 2007; FEITOSA et al., 2004; FÉRES et al., 2009; CARDOSO et al., 2008).

Young animals are expected to have a higher risk for infection, as compared to the adults; however, our results indicated no difference in the occurrence of Cryptosporidium between calves $(16.8 \%)$ and cows $(10.2 \%)$, possibly due to the similar infection rates observed in calves and cows (12.2 and $10.8 \%$, respectively) or the low number of cows analyzed $(n=12)$. Beef cows and calves live in the same environment, which possibly accounts for the similar infection rates between these sub-groups. Genotypic analyses would be necessary to confirm this hypothesis, since distinct species of Cryptosporidium infect animals of different ages. Dairy calves are separated from their mothers, and usually maintained under unhygienic conditions, which could explain the trend toward higher occurrence rates in calves than in milk cows. In previous comparative studies, Coklin et al. (2007) evaluated 143 dairy cows and found an infection rate of zero (0\%) in cows and $39.6 \%$ in calves. Cardoso et al. (2008) reported Cryptosporidium infection rates of $1.8 \%$ in calves (aged 0-6 months) vs. $0.35 \%$ in cows and heifers; and Gow \& Waldner (2006) reported 1.1\% (5/560) in beef cows and 3.1\% (19/605) in beef calves.

The similar rate of occurrence of Cryptosporidium in young and adult animals found in this study could also be explained by a high infection rate in adult cattle by $C$. andersoni. This species is found in animals from 1 year of age to older animals (up to 2 years old), often asymptomatic bearers of environmental contamination (ROBINSON et al., 2006)

Cryptosporidium infections in beef cattle are not frequent (HECKLER et al., 2015). In Brazil, Cardoso et al. (2008) found only $0.4 \%$ of cows to be positive for Cryptosporidium in the municipality of Caçapava, São Paulo. Ralston et al. (2003), and Gow \& Waldner (2006) also identified a low prevalence of Cryptosporidium in calves and were among the few researchers to evaluate beef cattle.

Of the 16 properties studied, $11(68.7 \%)$ had at least one animal that was positive for Cryptosporidium. All properties in the municipalities of Assaí (2/2), Ibaiti (2/2), and Leópolis (2/2) had infected animals. Half of the Santo Antônio da Platina properties (50\%) and $66.7 \%$ of the Ribeirão do Pinhal properties had positive animals (Table 2). Epidemiological studies of parasitic diseases in the North Pioneer mesoregion are scarce. However, the few studies on ruminants in this region have shown high parasite loads, which may reflect poor sanitary conditions and inadequate handling of these animals (HOLSBACK et al., 2013, 2015, 2016).

It was concluded that Cryptosporidium occurs in most municipalities assessed, that dairy calves have a higher risk for infection than beef calves, and that sheep are just as susceptible to infection as cattle. This was the first epidemiological study of cryptosporidiosis in ruminants in the North Pioneer mesoregion of Paraná.

\section{Acknownledgment}

To Fundação Araucária/PR for financing this study. Beneficiary of financial assistance CAPES e Fundaçáo Araucária/PR - Brazil.

\section{References}

Allen AVH, Ridley DS. Further observations on the formol-ether concentration technique for faecal parasites. J Clin Pathol 1970; 23(6): 545-546. http://dx.doi.org/10.1136/jcp.23.6.545. PMid:5529256.

Aquino MCC, Widmer G, Zucatto AS, Viol MA, Inácio SV, Nakamura AA, et al. First molecular characterization of Cryptosporidium spp. infecting buffalo calves in Brazil. J Eukaryot Microbiol 2015; 62(5): 657-661. http:// dx.doi.org/10.1111/jeu.12223. PMid:25941018.

Ayinmode AB, Olakunle FB, Xiao L. Molecular characterization of Cryptosporidium spp. in native calves in Nigeria. Parasitol Res 2010; 107(4): 1019-1021. http://dx.doi.org/10.1007/s00436-010-1972-1. PMid:20644959.

Cardoso JMS, Silveira FL, Araújo AJUS, Carvalho JCC, Kanamura HY. Ocorrência de Cryptosporidium spp. em um rebanho bovino leiteiro no município de Caçapava, estado de São Paulo, Brasil. Rev Bras Parasitol Vet 2008; 17(Supl S1): 239-242. 
Causapé AC, Quílez J, Sánchez-Acedo C, del Cacho E, López-Bernad F. Prevalence and analysis of potential risk factors for Cryptosporidium parvum infection in lambs in Zaragoza (northeastern Spain). Vet Parasitol 2002; 104(4): 287-298. http://dx.doi.org/10.1016/S0304-4017(01)00639-2. PMid:11836029.

Clode PL, Koh WH, Thompson RCA. Life without a host cell: what is Cryptosporidium? Trends Parasitol 2015; 31(12): 614-624. http://dx.doi. org/10.1016/j.pt.2015.08.005. PMid:26440789.

Coelho WMD, Widmer G, Oliveira FP, Amarante AFT, Bresciani KDS. Natural infection by Cryptosporidium spp. in production animals: first description of subtype IIaA15G2R1 in goat kids and piglets in Brazil. Rev Patol Trop 2016; 45(4): 361-368. http://dx.doi.org/10.5216/rpt. v45i4.44639.

Coklin T, Farber J, Parrington L, Dixon B. Prevalence and molecular characterization of Giardia duodenalis and Cryptosporidium spp. in dairy cattle in Ontario, Canada. Vet Parasitol 2007; 150(4): 297-305. http:// dx.doi.org/10.1016/j.vetpar.2007.09.014. PMid:17964724.

Cosendey RIJ, Fiuza VRS, Teixeira CS, Oliveira FCR. Freqüência de oocistos de coccídios do gênero Cryptosporidium em ovinos no estado do Rio de Janeiro. Rev Bras Saúde Prod Anim 2008; 9(4): 687-669.

Couto MCM, Lima MF, Bomfim TCB. New Cryptosporidium parvum subtypes of IIa subfamily in dairy calves from Brazil. Acta Trop 2014; 130: 117-122. http://dx.doi.org/10.1016/j.actatropica.2013.11.002. PMid:24239750.

Ederli BB, Carvalho CB, Sales LG. Ocorrência da infecçáo por Cryptosporidium em bezerros na microrregiâo de Campos dos Goytacazes no norte do Estado do Rio de Janeiro, Brasil. Rev Bras Parasitol Vet 2004; 13(2): 45-48.

Fayer R, Santín M, Trout JM. Cryptosporidium ryanae n. sp. (Apicomplexa: Cryptosporidiidae) in cattle (Bos taurus). Vet Parasitol 2008; 156(3-4): 191 198. http://dx.doi.org/10.1016/j.vetpar.2008.05.024. PMid:18583057.

Feitosa FLF, Shimamura GM, Roberto T, Meireles MV, Nunes CM, Ciarlini PC, et al. Prevalência de Criptosporidiose em bezerros na região de Araçatuba, Estado de Sáo Paulo, Brasil. Cienc Rural 2004; 34(1): 189193. http://dx.doi.org/10.1590/S0103-84782004000100029.

Féres FC, Lombardi AL, Carvalho MPP, Mendes LCN, Peiró JR, Cadioli FA, et al. Ocorrência e caracterização molecular de Cryptosporidium em cordeiros. Arq Bras Med Vet Zootec 2009; 61(4): 1002-1005. http://dx.doi. org/10.1590/S0102-09352009000400033.

Fiuza VR, Cosendey RI, Frazão-Teixeira E, Santín M, Fayer R, Oliveira FC. Molecular characterization of Cryptosporidium in Brazilian sheep. Vet Parasitol 2011; 175(3-4): 360-362. http://dx.doi.org/10.1016/j. vetpar.2010.10.036. PMid:21075526.

Fujii KY, Dittrich JR, Castro EA, Almeida JC. Ocorrência de Cryptosporidium spp em dois centros de treinamento de equinos de Curitiba, Paraná. Braz J Vet Res Anim Sci 2014; 51(2): 118-121. http://dx.doi.org/10.11606/ issn.2318-3659.v51i2p118-121.

Garcia AM, Lima JD. Frequência do Cryptosporidium em bezerros lactentes de rebanhos leiteiros de Minas Gerais. Arq Bras Med Vet Zootec 1993; 45(2): 193-198.

Garcia AM, Lima JD. Prevalência de Cryptosporidium spp em rebanhos leiteiros de Pará de Minas (M.G.) e sua relação com práticas de manejo. Rev Bras Parasitol Vet 1994; 3(1): 23-28.

Gow S, Waldner C. An examination of the prevalence of and risk factors for shedding of Cryptosporidium spp. and Giardia spp. in cows and calves from western Canadian cow - calf herds. Vet Parasitol 2006; 137(1-2): 50-61. http://dx.doi.org/10.1016/j.vetpar.2005.05.071. PMid:16472921.

Heckler RP, Borges DGL, Bacha FB, Onizuka MKV, Teruya LS, Neves JPL, et al. First genetic identification of Cryptosporidium parvum subtype IIaA14G2R1 in beef cattle in Brazil. Prev Vet Med 2015; 121(3-4): 391-394. http://dx.doi.org/10.1016/j.prevetmed.2015.08.016. PMid:26342791.

Holsback L, Luppi PAR, Silva CS, Negrão GK, Conde G, Gabriel $\mathrm{HV}$, et al. Anthelmintic efficiency of doramectin, fenbendazole, and nitroxynil, in combination or individually, in sheep worm control. Rev Bras Parasitol Vet 2016; 25(3): 353-358. http://dx.doi.org/10.1590/ S1984-29612016025. PMid:27096532.

Holsback L, Marquez ES, Meneghel PP. Resistência parasitária de helmintos gastrointestinais e avaliação dos parâmetros hematológicos de ovinos no norte do Paraná. Rev Bras Med Vet 2013; 35(1): 76-84.

Holsback L, Silva MA, Patelli THC, Jesus AP, Sanches JR. Resistance of Haemonchus, Cooperia, Trichostrongylus, and Oesophagostomum to ivermectin in dairy cattle in Paraná. Semina: Ciênc Agrár 2015; 36(3): 2031-2036. http://dx.doi.org/10.5433/1679-0359.2015v36n3Supl1p2031.

Kvác M, Vitovec J. Prevalence and pathogenicity of Cryptosporidium andersoni in one herd of beef cattle. J Vet Med B Infect Dis Vet Public Health 2003; 50(9): 451-457. http://dx.doi.org/10.1046/j.09311793.2003.00701.x. PMid:14633200.

Levine ND. Phylum II Apicomplexa. In: Lee JJ, Hutner SH, Bovee EC, editors. An illustrated guide to the protozoa. Lawrence: Allen Press; 1985. p. 322-374.

Lima RCA, Aquino MCC, Inácio SV, Viol MA, Zucatto AS, Silveira L No, et al. Caracterização molecular de Cryptosporidium spp. em bezerros (Bos taurus e Bos indicus) no município de Formiga, Minas Gerais Brasil. Semina: Ciênc Agrár 2013; 34(6): 3747-3754. http://dx.doi. org/10.5433/1679-0359.2013v34n6Supl2p3747.

Majewska AC, Werner A, Sulima P, Luty T. Prevalence of Cryptosporidium in sheep and goats bred on five farms in west-central region of Poland. Vet Parasitol 2000; 89(4): 269-275. http://dx.doi.org/10.1016/S03044017(00)00212-0. PMid:10799840.

Martinez I, Belda FM No. Contribution to the laboratory diagnosis of human cryptosporidiosis. Rev Inst Med Trop São Paulo 2001; 43(2): 79-82. http://dx.doi.org/10.1590/S0036-46652001000200005. PMid:11340480.

Morgan UM, Pallant L, Dwyer BW, Forbes DA, Rich G, Thompson RCA. Comparison of PCR and microscopy for detection of Cryptosporidium parvum in human fecal specimens: clinical trial. J Clin Microbiol 1998; 36(4): 995-998. PMid:9542924.

Nakamura AA, Simóes DC, Antunes RG, Silva DC, Meireles MV Molecular characterization of Cryptosporidium spp. from fecal samples of birds kept in captivity in Brazil. Vet Parasitol 2009; 166(1-2): 47-51. http://dx.doi.org/10.1016/j.vetpar.2009.07.033. PMid:19683397.

Navarro IT, Kano FS, Ogawa L, Freire RL, Vidotto O. Ocorrência de Cryptosporidium spp em cáes com diarréia atendidos no Hospital Veterinário da Universidade Estadual de Londrina, PR, Brasil. Semina: Ciênc Agrár 1997; 18(1): 23-25.

Paz e Silva FM, Lopes RS, Araújo-Júnior JP. Identification of Cryptosporidium species and genotypes in dairy cattle in Brazil. Rev Bras Parasitol Vet 2013; 22(1): 22-28.

Paz e Silva FM, Lopes RS, Bresciani KD, Amarante AF, Araujo JP Jr. High occurrence of Cryptosporidium ubiquitum and Giardia duodenalis genotype E in sheep from Brazil. Acta Parasitol 2014; 59(1): 193-196. http://dx.doi.org/10.2478/s11686-014-0223-5. PMid:24570068. 
Ralston BJ, Cockwill CL, Guselle NJ, Van Herk FH, McAllister TA, Olson ME. Prevalence of Giardia and Cryptosporidium andersoni and their effects on performance in feedlot beef cattle. Can J Anim Sci 2003; 83(1): 153-159. http://dx.doi.org/10.4141/A01-001.

Rekha HKM, Puttalakshmamma GC, D'Souza PE. Comparison of different diagnostic techniques for the detection of cryptosporidiosis in bovines. Vet World 2016; 9(2): 211-215. http://dx.doi.org/10.14202/ vetworld.2016.211-215. PMid:27051211.

Robinson G, Thomas AL, Daniel RG, Hadfield SJ, Elwin K, Chalmers RM. Sample prevalence and molecular characterisation of Cryptosporidium anderson $i$ within a dairy herd in the United Kingdom. Vet Parasitol 2006; 142(1-2): 163-167. http://dx.doi.org/10.1016/j.vetpar.2006.06.031. PMid:16908101.

Santín M, Trout JM, Fayer R. Prevalence and molecular characterization of Cryptosporidium and Giardia species and genotypes in sheep in Maryland. Vet Parasitol 2007; 146(1-2): 17-24. http://dx.doi.org/10.1016/j. vetpar.2007.01.010. PMid:17335979.

Santín M, Trout JM, Fayer R. A longitudinal study of cryptosporidiosis in dairy cattle from birth to 2 years of age. Vet Parasitol 2008; 155(1-2): 15-23. http://dx.doi.org/10.1016/j.vetpar.2008.04.018. PMid:18565677.

Sevá AP, Funada MR, Souza SO, Nava A, Richtzenhain LJ, Soares RM. Occurrence and molecular characterization of Cryptosporidium spp. isolated from domestic animals in a rural area surrounding Atlantic dry forest fragments in Teodoro Sampaio municipality, State of São Paulo, Brazil. Rev Bras Parasitol Vet 2010; 19(4): 249-253. http://dx.doi.org/10.1590/ S1984-29612010000400011. PMid:21184703.

Silva FM, Lopes RS, Araújo-Junior JP. Identification of Cryptosporidium species and genotypes in dairy cattle in Brazil. Rev Bras Parasitol Vet 2013; 22(1): 22-28. http://dx.doi.org/10.1590/S1984-29612013005000010. PMid:23538500.

Silva-Junior FA, Carvalho AHO, Rocha CMBM, Guimarães AM. Fatores de risco associados à infecção por Cryptosporidium spp e Giardia duodenalis em bovinos leiteiros na fase de cria e recria na mesorregião do Campo das Vertentes de Minas Gerais. Pesq Vet Bras 2011; 31(8): 690-696. http:// dx.doi.org/10.1590/S0100-736X2011000800010.

Snak A, Garcia FG, Delgado LES, Osaki SC. Occurrence of Cryptosporidium spp. in wild animals living in the Cascavel city park, Paraná, Brazil. Semina:
Ciênc Agrár 2015; 36(6): 4323-4332. http://dx.doi.org/10.5433/16790359.2015v36n6Supl2p4323.

Snak A, Smiderle FR, Fernandes NLM, Lara AA, Garcia FG, Ogawa $\mathrm{L}$, et al. Ocurrence and molecular characterization of Cryptosporidium sp. in sheep. Semina: Ciênc Agrár 2017; 38(4): 1917-1924. http://dx.doi. org/10.5433/1679-0359.2017v38n4p1917.

Tahvildar-Biderouni F, Salehi N. Detection of Cryptosporidium infection by modified ziehl-neelsen and PCR methods in children with diarrheal samples in pediatric hospitals in Tehran. Gastroenterol Hepatol Bed Bench 2014; 7(2): 125-130. PMid:24834304.

Toledo RS, Martins FDC, Ferreira FP, Almeida JC, Ogawa L, Santos HLEPL, et al. Cryptosporidium spp. and Giardia spp. in feces and water and the associated exposure factors on dairy farms. PLoS One 2017; 12(4): e0175311. http://dx.doi.org/10.1371/journal.pone.0175311. PMid:28403147.

Villacorta I, Ares-Mazas E, Lorenzo MJ. Cryptosporidium parvum in cattle, sheep and pigs in Galicia (N.W. Spain). Vet Parasitol 1991; 38(2-3): 249252. http://dx.doi.org/10.1016/0304-4017(91)90134-H. PMid:1858293.

Wells B, Shaw H, Hotchkiss E, Gilray J, Ayton R, Green J, et al. Prevalence, species identification and genotyping Cryptosporidium from livestock and deer in a catchment in the Cairngorms with a history of a contaminated public water supply. Parasit Vectors 2015; 8(1): 66. http:// dx.doi.org/10.1186/s13071-015-0684-x. PMid:25650114.

Xiao L, Escalante L, Yang C, Sulaiman I, Escalante AA, Montali RJ, et al. Phylogenetic analysis of Cryptosporidium parasites based on the smallsubunit rRNA gene locus. Appl Environ Microbiol 1999; 65(4): 15781583. PMid:10103253.

Xiao L, Herd RP, Rings DM. Diagnosis of Cryptosporidium on a sheep farm with neonatal diarrhea by immunofluorescence assays. Vet Parasitol 1993; 47(1-2): 17-23. http://dx.doi.org/10.1016/0304-4017(93)90172-J. PMid:8493764.

Zucatto AS, Aquino MCC, Inácio SV, Figueiredo RN, Pierucci JC, Perri SHV, et al. Molecular characterisation of Cryptosporidium spp. in lambs in the South Central region of the State of São Paulo. Arq Bras Med Vet Zootec 2015; 67(2): 441-446. http://dx.doi.org/10.1590/1678-7067. 